\title{
SHORT NOTES
}

\section{THE DISTRIBUTION OF GLACIERS IN THE ROCKY MOUNTAINS OF THE UNITED STATES}

\author{
By W. L. GraF \\ (Department of Geography, University of Iowa, Iowa City, Iowa $5224^{2}$, U.S.A.)
}

\begin{abstract}
Evidence from aerial photographs, maps, and field checks indicates that 319 glaciers lie in cirques of the Rocky Mountains, south of the United States-Canadian border. On a subcontinental scale, the distribution of glaciers is highly clustered, with larger and denser clusters located in the northern Rocky Mountains. Lesser concentrations of small glaciers occur in the southern Rocky Mountains. The total area of glaciers in the Rocky Mountains of the U.S.A. is $78.9 \mathrm{~km}^{2}$.
\end{abstract}

RÉsumÉ. La distribution des glaciers dans les Rocky Mountains des États-Unis. Photographies aériennes, cartes, observations de terrain montrent que 319 glaciers occupent des cirques dans les Rocky Mountains au Sud de la frontière États-Unis-Canada. A une échelle subcontinentale la distribution des glaciers est largement groupée avec des groupes plus grands et plus denses dans le Nord des Rocky Mountains. De moindres concentrations de petits glaciers se produisent dans le Sud des Rocky Mountains. Le total de la zone englaciée dans les Rocky Mountains des États-Unis est de $78,9 \mathrm{~km}^{2}$.

Zusammenfassung. Die Verteilung der Gletscher in den US-amerikanischen Rocky Mountains. Aus Luftbildern, Karten und Feldbeobachtungen lässt sich feststellen, dass 319 Gletscher in Karen der Rocky Mountains südlich der Grenze zwischen den USA und Kanada liegen. Subkontinental gesehen weist die Verteilung der Gletscher signifikante Häufungen auf, deren Grösse und Dichte in den nördlichen Rocky Mountains zunimmt. Geringere Häufung kleiner Gletscher ist in den südlichen Rocky Mountains anzutreffen. Das gesamte vergletscherte Areal in den US-amerikanischen Rocky Mountains umfasst $78,9 \mathrm{~km}^{2}$.

\section{INTRODUCTION}

Glaciers are an integral part of many alpine landscapes in the Rocky Mountains. Most of the alpine landscapes have been shaped by predecessors of the present ice masses, while present locations and distributions of the glaciers exert profound influences on the hydrologic systems of the mountains and the water supply. An understanding and appreciation of the geography of the Rocky Mountains would be incomplete without an analysis of the distribution of glaciers, but lack of an adequate data base has hampered a complete census of ice bodies. This note presents evidence from recent aerial photography, maps, and field checks towards an account of glacier distributions south of the United States-Canadian border.

\section{GLacier census}

Research workers have been documenting glaciers and their activity in the Rocky Mountains for almost a century. Three attempts have been made at a complete census of all glaciers in the Rocky Mountains. The earliest scientific reports were by Hayden (1878[a], 1878[b]) and Holmes (1878). Russell's early work focussed on a few well-known areas of the Rocky Mountains, but made no attempt at a complete census (Russell, 1885, 1897). The monumental work of Dyson (1952) was the first effort to collate aerial photograph references for all glaciers of the Rocky Mountains, but many of the photographs were small scale and of poor quality. Dyson frequently relied on second-hand reports from untrained observers, such as forest rangers, for supporting evidence. Meier (I96I) later refined the glacier count, but some field experience of the present author has revealed inadequacies in his accounting. Denton's general work is the most complete account to date, but provides little new information and perpetuates previous errors (Denton, 1975). Since the time of the major studies, new, high-quality, large-scale photography has been made available by the U.S. Forest Service and the U.S. Geological Survey. This is supplemented by numerous topographic maps with scales as large as $1: 24$ ooo.

In the present study, glaciers were initially identified and outlined for study on U.S. Geological Survey or U.S. Forest Service aerial photographs at scales ranging from $1: 15000$ to $1: 31$ ooo. 
Selection of the photographs is crucial, particularly with respect to date, because snow cover lingers late in spring and early summer. The last week in August or the first week in September offers the best chance for good aerial photos for the alpine areas of the Rocky Mountains because early fall storms leave snow in mid-September. Even during this later period, it is often difficult to differentiate between snow banks and glaciers, but field checks have revealed three primary lines of evidence: visible ice, evidence of movement, and crevasses.

In many cases, glacial ice is visible in the photographs; this resolves all questions of identification. Glacial ice is darker than surrounding snow, and at scales from $1: 15000$ to $1: 31$ ooo ice usually has a coarser texture than powdered or granular snow. Evidence of past movement usually consists of concentric morainic ridges about the lower end of the glacier. Protalus ramparts occasionally present a moraine-like appearance, but they occur much closer to the cirque or valley wall than do true moraines. Ramparts are usually sharp-crested crescents that may be lined end to end, but they rarely form concentric rings (Daly, 1912; Richmond, 1962). Crevasse patterns provide the final clues in the differentiation between small glaciers and snow banks. In the small glaciers of the Rocky Mountains, crevasses are almost always sharply defined transverse cracks with noticeable curvature. Such crevasses may occur anywhere on the glaciers, but most commonly they form bergschrunds near the tops of glaciers, and calving crevasses near the bottoms. Snow banks may develop bergschrunds in rare cases, but

Table I. Glacier census

\begin{tabular}{|c|c|c|c|c|}
\hline Mountain unit & $\begin{array}{c}\text { Number of } \\
\text { glaciers }\end{array}$ & $\begin{array}{c}\text { Glacierized } \\
\text { area } \\
\mathrm{km}^{2}\end{array}$ & $\begin{array}{c}\text { Mean glacier } \\
\text { size } \\
\mathrm{km}^{2}\end{array}$ & $\begin{array}{l}\text { Mean shape } \\
\text { (length/width }\end{array}$ \\
\hline Cabinet & 2 & 0.505 & 0.252 & 1.919 \\
\hline Livingstone & $4^{r}$ & 10.577 & $0.25^{8}$ & I. 384 \\
\hline Lewis & 70 & I 7.757 & 0.253 & 1.060 \\
\hline Flathead & 2 & 0.674 & 0.337 & 0.479 \\
\hline Swan & 6 & 0.612 & 0.102 & 1. $35^{8}$ \\
\hline Mission & 6 & 1.012 & $0.15^{6}$ & I. 286 \\
\hline Crazy* & 4 & 0.400 & 0.100 & I. 100 \\
\hline Beartooth & 71 & Io.89 I & 0.153 & 1.527 \\
\hline Bighorn & 9 & 0.974 & 0.108 & 1. 302 \\
\hline Absaroka* & 9 & 0.720 & 0.080 & I.000 \\
\hline Teton & 12 & 1.657 & o. $13^{8}$ & 1. 878 \\
\hline Wind River & 64 & $3^{1} \cdot 57^{8}$ & 0.493 & 1.816 \\
\hline Front Range & 23 & I.495 & 0.065 & I. 589 \\
\hline Totals & 319 & $78.8_{52}$ & - & - \\
\hline
\end{tabular}

* Areas of poor map and photo coverage.

compaction prevents crevasses from forming near the bottom. Rapid glacier retreat during the early rgoo's has made the following situation common: a steep glacier front (frequently with crevasses), with a small evacuated basin immediately down valley, and a recent moraine built before ${ }_{1} 850$ that dams a small lake of melt water. Permanent snow banks do not normally occur in a similar situation unless the pre-existing glacier has completely melted and has been replaced by permanent snow, an unlikely circumstance given the relatively small magnitude of climatic changes in the last few decades.

Table I and Figure I show the census of glaciers in the Rocky Mountains as determined from aerial photography and ground checks. For the purpose of this study a glacier is defined as a body of ice, with a surface area equal to or greater than $0.05 \mathrm{~km}^{2}$ (about II.5 acres), originating on land from recrystallization of solid precipitation, and showing evidence of past or present movement. Substantive parts of the definition are borrowed from Flint (197I), but the size limit is designed to include ice bodies traditionally considered in the literature as "glaciers".

The mean shapes of the glaciers were calculated by measuring the length from highest to lowest points and then dividing this value by the maximum width. Measurements were made photogrammetrically with ground checks in questionable areas. A shape value greater than r.o indicates that the glacier is longer than it is wide, forming a tongue of ice. A shape value less than r.o indicates a glacier that is wider than it is long, while a value close to 1.0 is typical of many cirque glaciers. 


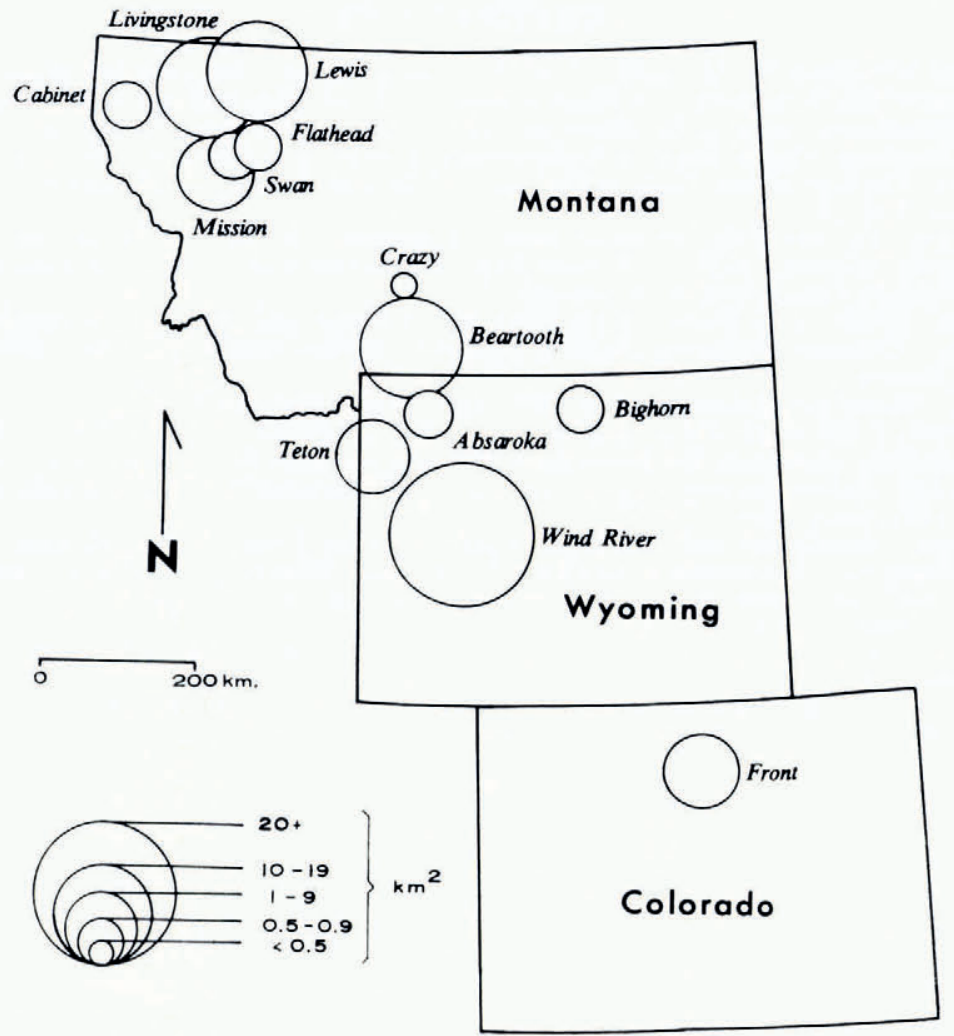

Fig. I. Glacierized area of the American Rocky Mountains.

The three major concentrations of glaciers in the Rocky Mountains south of the United StatesCanadian border (the Livingstone and Lewis Ranges in Glacier National Park, the Beartooth Range in southern Montana, and the Wind River Range in west-central Wyoming) account for more than $75 \%$ of the total number of glaciers and $89 \%$ of the total area covered by glacial ice. The total number of glaciers given here exceeds earlier estimates by Dyson and Meier partly because of the photographic coverage which is more complete and is of better quality than that available to previous workers. The total glacierized area exceeds the Meier (196I) estimate by about $15 \%$.

The largest glaciers are concentrated in the Wind River Range, which contains $20 \%$ of the glaciers by number, but $40 \%$ by area. This result may be contrasted with that for the Front Range, which has $7 \%$ of the glaciers, but less than $2 \%$ of the glacierized area. Glaciers in the Front Range are small. This is apparently a response to the climatic conditions associated with the low latitude of the range. Although glaciers generally become more numerous as distance from the equator increases, the distribution of glaciers in the Rocky Mountains province is highly clustered with the larger and denser clusters occurring in the north.

Part of the explanation of the distribution of glaciers in the Rocky Mountains is concerned with air-mass domination. All existing glaciers in the region are inside the area occupied by mild Pacific air masses for more than $50 \%$ of the time (as mapped by Bryson and Wendland, 1967 ). The southern boundary of the glacier zone coincides with the boundary between the Pacific-dominated area and regions more strongly affected by the warm dry continental air originating in the interior south-western United States.

MS. received 3 August 1976 and in revised form 9 September 1976 


\section{REFERENCES}

Bryson, R. A., and Wendland, W. M. 1967 . Tentative climatic patterns for some late-glacial and post-glacial episodes in central North America. (In Mayer-Oakes, W. J., ed. Life, land and water. Proceedings of the I966 conference on environmental studies of the glacial lake Agassiz region. Winnipeg, University of Manitoba Press, p. 27 I-98. (Occasional Papers, Dept. of Anthropology, University of Manitoba, No. 1.))

Daly, R. A. 1912. Geology of the North American cordillera at the forty-ninth parallel. Canada. Geological Survey. Memoirs, Vol. 38 .

Denton, G. H. 1975. Glaciers of the American Rocky Mountains. (In Field, W. O., ed. Mountain glaciers of the northern hemisphere. Hanover, N.H., U.S. Cold Regions Research and Engineering Laboratory. Technical Information Analysis Center, Vol. 1, p. 509-42.)

Dyson, J. L. 1952. Glaciers of the American Rocky Mountains. Triennial report 1950-52. Subcommittee on the American Rocky Mountains. Committee on Glaciers, Section of Hydrology, American Geophysical Union. New York, American Geographical Society.

Flint, R. F. 1971. Glacial and Quaternary geology. New York, John Wiley and Sons.

Hayden, F. V. 1878 [a]. Discovery of Recent glaciers in Wyoming. American Naturalist, Vol. 12, No. 11, p. 830-31.

Hayden, F. V. $1878[\mathrm{~b}]$. Glaciers in the Wind River Mountains. Science Neres, Vol. I, No. 1, p. 20-2 I.

Holmes, W. H. 1878 . Report on the geology of the Yellowstone National Park. U.S. Geological Survey. Survey of the Territories, i 2 th Annual Report, Vol. 2.

Meier, M. F. 196r. Distribution and variations of glaciers in the United States exclusive of Alaska. Union Géodésique et Géophysique Internationale. Association Internationale d'Hydrologie Scientifique. Assemblée générale de Helsinki, 25-7-6-8 196o. Commission des Neiges et Glaces, p. 420-29. (Publication No. 54 de l'Association Internationale d'Hydrologie Scientifique.)

Richmond, G. M. 1962. Quaternary stratigraphy of the La Sal Mountains, Utah. U.S. Geological Survey. Professional Paper 324 .

Russell, I. C. 1885 . Existing glaciers of the United States. U.S. Geological Survey, 5th Annual Report, p. $344-47$.

Russell, I. C. 1897. Glaciers of North America. Boston, Sharp. 